\title{
Prisotnost geografov in pomen geografije $v$ inštitucijah regionalnega planiranja
}

\author{
Simon Kušar \\ Oddelek za geografijo, Filozofska fakulteta, Univerza v Ljubljani, \\ Aškerčeva 2, 1000 Ljubljana, Slovenija \\ e-mail: simon.kusar@ff.uni-lj.si
}

\section{Izvleček}

Po sprejetju Zakona o spodbujanju skladnega regionalnega razvoja leta 1999 so se začele oblikovati inštitucije, ki skrbijo za skladen regionalni razvoj. Kakšno vlogo imajo v njih geografi, smo poskušali ugotoviti s pomočjo ankete. Iz podatkov o številu geografov, ki v njih delujejo, možnostih novih zaposlitev ter zbranih prednosti in slabosti geografov, lahko sklepamo na aplikativno vrednost geografije $v$ regionalnem planiranju v Sloveniji danes.

Ključne besede: geografska teorija, slovenska geografija, regionalno planiranje, inštitucije regionalnega planiranja, Slovenija

\section{Geographers and Geography in the Institutions of Regional Planning}

\begin{abstract}
After 1999, when legislation in the field of regional planning in Slovenia had been changed, new institutions of regional planning have emerged. The role of geographers in those institutions was examined with a questionnaire. From collected information about the number of geographers involved into regional planning, potential new employment, advantages and disadvantages of geographers we can figure out the applicative role of geography in regional planning in Slovenia today.
\end{abstract}

Key words: geographical theory, slovene geography, regional planning, institutions of regional planning, Slovenia 


\section{UVOD}

Številni avtorji (na primer Drozg in Premzl, 1999; Kukar, 1995; Ravbar, 2000; Vrišer, 1999) so opozarjali, da je bila regionalna politika v začetku 90. let 20. stoletja neustrezna in zato potrebna prenove. Zajemala je le območja s specifičnimi demografskimi gibanji. Uporabljeni so bili kazalci o staranju in gibanju prebivalstva, ki ne povedo nič o novejših regionalnih problemih, zlasti o strukturni krizi v nekaterih regijah.

Zaradi potrebe po novem pristopu $\mathrm{k}$ spodbujanju regionalnega razvoja in zaradi prilagajanja sistema regionalne politike Evropski uniji (Kavaš et al, 2000) je bila sprejeta nova pravna podlaga za spodbujanje regionalnega razvoja. Zakon o spodbujanju skladnega regionalnega razvoja je bil sprejet leta 1999 (Uradni list RS, 60/99). Zakon določa poleg ciljev in načel spodbujanja skladnega regionalnega razvoja, dodeljevanja razvojnih spodbud ter meril za določitev območij s posebnimi razvojnimi problemi tudi novo organizacijo spodbujanja skladnega regionalnega razvoja (Zakon o spodbujanju skladnega regionalnega razvoja; v nadaljevanju ZSRR). Nosilci regionalne strukturne politike so Svet za strukturno politiko, Agencija Republike Slovenije za regionalni razvoj, Sklad za regionalni razvoj in ohranjanje poseljenosti slovenskega podeželja ter regionalne razvojne agencije (ZSRR, 14. člen, 1. odstavek).

Svet za strukturno politiko je usklajevalni organ vlade. Njegovi člani so ministri in državni sekretarji, ki odločajo o politiki regionalnega razvoja. Agencija Republike Slovenije za regionalni razvoj deluje v okviru ministrstva pristojnega za razvoj. Njene naloge so zelo pomembne, saj opravlja številne razvojne, svetovalne, pospeševalne in usklajevalne naloge države pri spodbujanju regionalnega razvoja. Agencija bedi nad delitvijo državnih sredstev, zbira in analizira podatke o porabi sredstev za potrebe spodbujanja regionalnega razvoja ter vrednoti učinke regionalnih razvojnih spodbud (ZSRR, 16. člen). Naloga Sklada za regionalni razvoj in ohranjanje poseljenosti slovenskega podeželja je zbiranje in dodeljevanje sredstev za regionalno strukturno politiko (ZSRR, 18. člen).

Zakon o spodbujanju skladnega regionalnega razvoja je predvidel ustanovitev regionalnih razvojnih agencij, ki naj bi delovale na ravni regij. Pripravljale naj bi regionalne razvojne programe ter opravljale druge naloge s področja regionalne strukturne politike, zlasti pri pospeševanju gospodarskega, socialnega, prostorskega in okoljskega razvoja. Regionalne razvojne agencije lahko ustanovijo občine ali druge osebe javnega in zasebnega prava. Občine se lahko za opravljanje nalog regionalne razvojne agencije pogodbeno dogovorijo z obstoječo gospodarsko družbo ali kakšno drugo organizacijo (ZSRR, 17. člen). 
Nova organizacija spodbujanja regionalnega razvoja zahteva številne spremembe in novosti pri inštitucionalni organizaciji države in regij. Za ustanovitev regionalnih razvojnih inštitucij so potrebni ustrezni kadri, ki bodo ob dodatnem usposabljanju sposobni odgovorno opravljati dolžnosti zapisane $\mathrm{v}$ Zakonu o spodbujanju skladnega regionalnega razvoja in naloge določene $\mathrm{v}$ podzakonskih aktih.

Regionalni razvojni programi so sestavljeni iz strateškega in izvedbenega dela. Strateški del mora opredeliti (geografsko-op. avtorja) okolje z vsemi njegovimi sestavinami, predvsem s tistimi, ki predstavljajo oviro v prihodnjem razvoju regije. Opredelijo se glavni razvojni problemi, ki so osnova za določitev programov, podprogramov in projektov. Ti so natančneje opredeljeni $\mathrm{v}$ izvedbenem delu regionalnega razvojnega programa (Navodilo..., 2000).

Regionalno planiranje je zaradi svojega kompleksnega in sintetičnega značaja navezano na dognanja številnih ved. S pomočjo njihovih znanstvenih izsledkov se lahko dokoplje do spoznanj o objektivni stvarnosti in razvojnih zakonitostih, kar mu omogoča bolj zanesljivo napovedovanje bodočega razvoja in usmerjanje razvoja. Regionalno planiranje se v prvi vrsti opira na štiri vede: ekonomijo, arhitekturo, geografijo in sociologijo (Vrišer, 1978, str. 15).

Geografija je veda o zemeljskem površju in medsebojnem součinkovanju fizičnogeografskih in družbenogeografskih dejavnikov, ki v medsebojnem prepletanju tvorijo edinstveno kombinacijo različnih dejavnikov (Vrišer, 1992). Geografi lahko s svojo metodologijo, to je $\mathrm{z}$ analizo, vrednotenjem in sintezo dejavnikov v pokrajini, preučevanjem vpliva različnih dejavnikov ter iskanjem splošnih zakonitosti v pokrajini, prispevajo pomemben delež pri delu regionalnih razvojnih agencij.

Predpostavlja se, da so geografi pomemben sooblikovalec današnjega regionalnega planiranja v Sloveniji, geografija pa ima pri planiranju pomembno aplikativno vrednost. Namen prispevka je s pomočjo ankete »Pomen geografov in geografije v inštitucijah regionalnega planiranja« preveriti hipotezo o pomenu geografov in geografije $\mathrm{v}$ inštitucijah, ki so bile oblikovane v skladu $\mathrm{z}$ zahtevami Zakona o spodbujanju skladnega regionalnega razvoja. Cilji so ugotoviti število geografov, ki so udeleženi pri delu v inštitucijah regionalnega planiranja, potencialne možnosti novih zaposlitev ter oceniti prednosti in slabosti geografov pri tem delu.

\section{METODA}

Anketa o pomenu geografov in geografije $\mathrm{v}$ inštitucijah regionalnega planiranja je vsebovala naslednja vprašanja: 
- izobrazbena struktura redno zaposlenih na regionalni razvojni agenciji polni delovni čas

- izobrazbena struktura redno zaposlenih na regionalni razvojni agenciji tretjinski delovni čas

- izobrazbena struktura honorarno zaposlenih na regionalni razvojni agenciji

- izobrazbena struktura zunanjih sodelavcev regionalne razvojne agencije (strokovno svetovanje, izdelava strateškega in/ali izvedbenega dela regionalnega razvojnega programa)

- kadrovska politika $v$ tekočem letu

- željena zaposlitev kadrov, če bi regionalne razvojne agencije imele neomejena finančna sredstva

- ocena pomena geografov

- prednosti/slabosti geografov pri delu na področju spodbujanja regionalnega razvoja

Vprašanja so bila delno zaprtega tipa, saj so bila zastavljena tako, da so v naprej ponujala možne odgovore. Če nobeden od ponujenih odgovorov ni ustrezal, je bilo mogoče prosto vpisati najustreznejšega.

Inštitucije regionalnega planiranja $\mathrm{v}$ Sloveniji so relativno majhne. $\mathrm{V}$ povprečju zaposlujejo manj kot 6 ljudi. Največ regionalnih agencij (68 \%) ima zaposlenih 4-7 delavcev. Tri agencije imajo več kot 10 zaposlenih.

Anketa je bila posredovana vsem regionalnim razvojnim agencijam, ki so v evidenci Agencije Republike Slovenije za regionalni razvoj (22 agencij vir: http://www.sigov.si/arr/), državnim agencijam, uradom oziroma sektorjem znotraj ministrstev, ki so pomembni za spodbujanje skladnega regionalnega razvoja, ter izbranim podjetjem, ki se ukvarjajo z izdelavo skupnih razvojnih programov ali so kako drugače pomembni pri spodbujanju lokalnega razvoja (OIKOS d.o.o., Svetovanje za razvoj, Vir pri Domžalah; Naš Laz, Center za razvoj podeželja, Brezovica; Prleška razvojna agencija, Ljutomer).

Odziv podjetij in agencij je bil zelo spodbuden. Izpolnjene ankete je vrnilo 19 agencij od skupaj 25 naslovnikov. Zaradi mrežne povezanosti regionalnih/lokalnih razvojnih agencij v Goriški statistični regiji je bilo dejansko prejetih 16 izpolnjenih anket, saj je krovna regionalna razvojna agencija ICRA d.o.o., Idrijsko cerkljanska razvojna agencija, odgovarjala tudi v imenu ostalih agencij. Vzorec vsebuje $76 \%$ celotne populacije in zajema celotno območje Slovenije - iz vsake od 12 statističnih regij je odgovarjala vsaj ena regionalna razvojna agencija. 


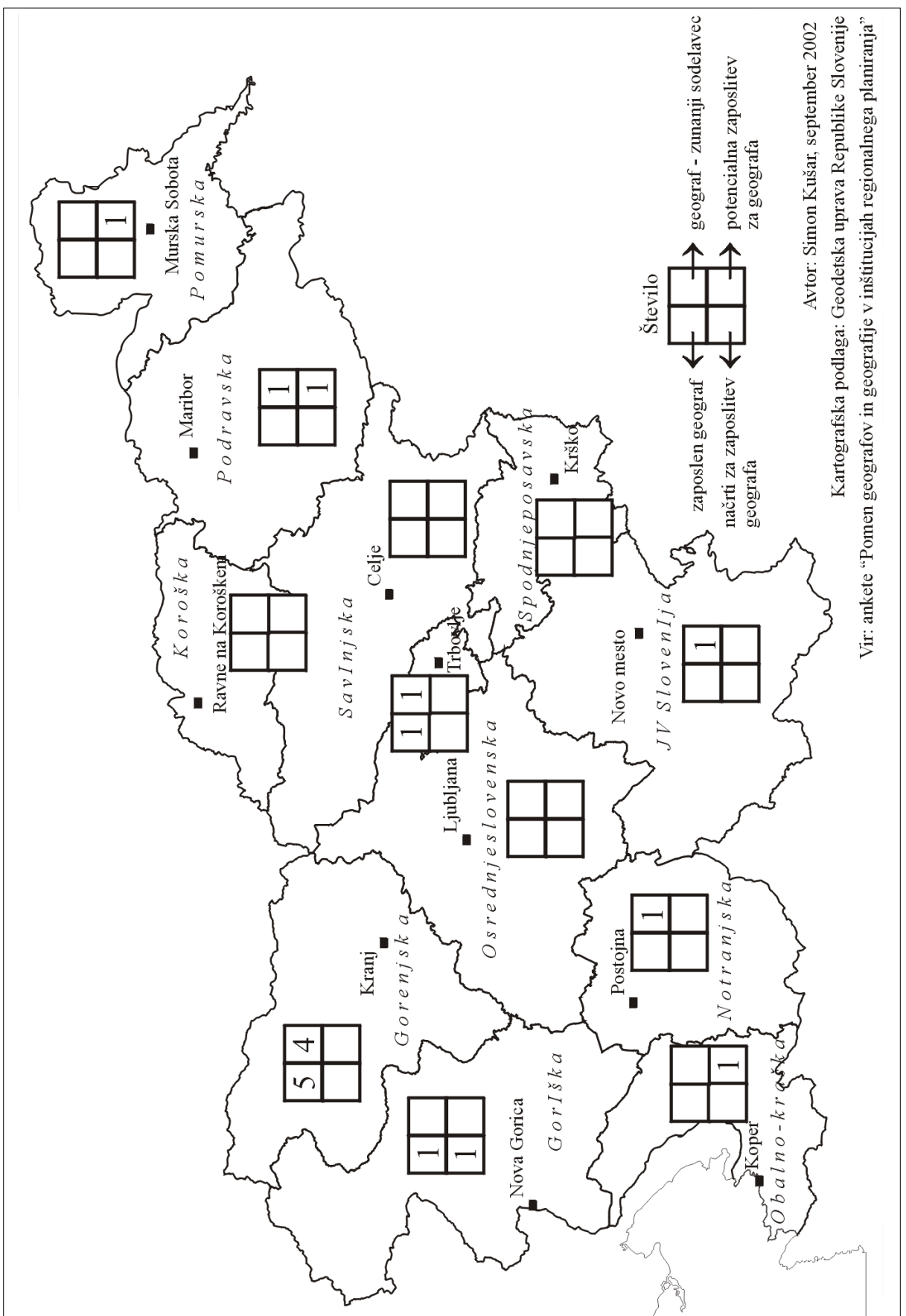

Slika 1: Geografi v regionalnih razvojnih agencijah - po statističnih regijah 
Ker je bil odziv državnih inštitucij skromen, so rezultati njihovih anket izvzeti iz nadaljne analize.

Preglednica 1: Sodelovanje inštitucij regionalnega planiranja $v$ anketi »Pomen geografov in geografije v inštitucijah regionalnega planiranja"

\begin{tabular}{|ll|l|}
\hline Regionalne/lokalne razvojne agencije, podjetja & Državne inštitucije \\
\hline - & Regionalna razvojna agencija Mura, Murska & Ministrstvo za okolje, \\
& Sobota & Urad za prostorsko \\
- & A.L.P. Peca, Črnaranje, Sektor za \\
- & RRA - Regionalna Razvojna Agencija Celje & $\begin{array}{l}\text { lokalno prostorsko } \\
\text { planiranje, Oddelek }\end{array}$ \\
- & Regionalni center za razvoj d.o.o., Zagorje & za prostorsko planiranje \\
- & Zavod Regijski pospeševalni center Posavje & na regionalni (medobčin- \\
- & Podjetniški center Novo mesto & ski) ravni \\
- & BSC - Poslovno podporni center d.o.o., Kranj & Ministrstvo za \\
- & Razvojna agencija SORA, Škofja Loka & gospodarstvo, Področje \\
- & Razvojna agencija RAGOR, Jesenice & regionalnega razvoja, \\
- & ICRA d.o.o., Idrijsko cerkljanska razvojna & Sektor za regionalno \\
& agencija & politiko \\
- & Posoški razvojni center, Kobarid & Ministrstvo za \\
- & Regijska razvojna agencija severne Primorske & gospodarstvo, Področje \\
& d.o.o., Nova Gorica & regionalnega razvoja, \\
- & ROD Razvojna agencija, Ajdovščina & Sektor za strukturno \\
- & RRA Notranjsko-Kraške regije, d.o.o., Pivka & politiko \\
- & Mariborska razvojna agencija, Maribor & Agencija Republike \\
- & Ekonomski inštitut Maribor & Slovenije za regionalni \\
- & ZRS Bistra Ptuj & razvoj \\
- & Regionalni razvojni center Koper & Javni sklad Republike \\
- & Center za pospeševanje podjetništva Piran & Slovenije za regionalni \\
- & PPC - Podjetniško pospeševalni center Sežana & razvoj in ohranjanje \\
- & Razvojni center Ilirska Bistrica & poseljenosti slovenskega \\
- & RRA Ljubljanske urbane regije, Ljubljana & podeželja \\
- & OIKOS d.o.o., svetovanje za razvoj, Vir pri & \\
- & Pomžalah & \\
- & Naš Laz, Center za razvoj podeželja, Brezovica & \\
\hline
\end{tabular}

Opomba: Krepak tisk: Agencija/inštitucija je sodelovala v raziskavi.

Pri anketah smo bili soočeni z nekaterimi standardnimi metodološkimi omejitvami. Pri izpolnjevanju ankete anketar ni bil prisoten, zato na kakovost izvedbe ni bilo mogoče vplivati. Nekateri anketiranci niso odgovorili na vsa vprašanja. Preveriti tudi ni mogoče, ali odgovori ustrezajo dejanskemu stanju. 


\section{ANALIZA REZULTATOV ANKET}

Inštitucije regionalnega planiranja v Sloveniji so relativno majhne. V povprečju zaposlujejo manj kot 6 ljudi. Največ regionalnih agencij (68 \%) ima zaposlenih 4-7 delavcev. Tri agencije imajo več kot 10 zaposlenih.

Preglednica 2: Izobrazbena struktura zaposlenih na regionalnih razvojnih agencijah in nove možnosti zaposlitve (anketa: vprašanja 1-6)

\begin{tabular}{|l|c|c|c|c|c|c|c|}
\hline & $\mathbf{1}$ & $\mathbf{2}$ & $\mathbf{3}$ & $\mathbf{4}$ & $\mathbf{5}$ & $\mathbf{6}$ & $\mathbf{7}$ \\
\hline agronom & 3 & 0 & 1 & 4 & 8 & 0 & 3 \\
\hline arhitekt & 1 & 0 & 0 & 1 & 10 & 2 & 1 \\
\hline biolog & 1 & 0 & 0 & 1 & 3 & 0 & 1 \\
\hline ekonomist & 45 & 1 & 2 & 48 & 22 & 5 & 8 \\
\hline geolog & 0 & 0 & 0 & 0 & 1 & 1 & 0 \\
\hline inženir gradbeništva & 1 & 0 & 0 & 1 & 5 & 1 & 5 \\
\hline inženir strojništva & 1 & 0 & 0 & 1 & 1 & 0 & 1 \\
\hline krajinski arhitekt & 0 & 0 & 1 & 1 & 4 & 2 & 6 \\
\hline geograf & 6 & 0 & 0 & 6 & 8 & 1 & 3 \\
\hline gozdar & 1 & 0 & 0 & 1 & 5 & 0 & 0 \\
\hline organizator dela & 7 & 1 & 0 & 8 & 2 & 2 & 1 \\
\hline pravnik & 3 & 0 & 0 & 3 & 4 & 4 & 9 \\
\hline sociolog & 4 & 2 & 1 & 7 & 5 & 0 & 5 \\
\hline administrativno osebje & 7 & 0 & 1 & 8 & 5 & 1 & 6 \\
\hline drugo & 30 & 1 & 0 & 31 & 7 & 4 & 4 \\
\hline skupaj & 110 & 5 & 6 & 121 & 90 & 23 & 53 \\
\hline
\end{tabular}

Legenda: 1-redna zaposlitev, 2-tretjinski delovni čas, 3-honorarna zaposlitev, 4-skupaj zaposleni, 5-zunanji sodelavci, 6-predvidene nove zaposlitve v letu 2002, 7-željene/potrebne zaposlitve.

Opomba: Zaposleni preko javnih del v preglednico 2 niso vključeni.

V regionalnih razvojnih agencijah, ki so sodelovale pri raziskavi, je redno zaposlenih 110 ljudi. Med njimi močno prevladujejo sodelavci z ekonomsko izobrazbo. Ekonomisti predstavljajo skoraj polovico vseh zaposlenih (41\%). Skoraj tretjina zaposlenih $(27 \%)$ ne sodi v nobeno rubriko od izbranih v anketi. To opozarja na izrazito heterogenost zaposlenih $\mathrm{v}$ regionalnih razvojnih agencijah. Po zbranih podatkih so $\mathrm{v}$ agencijah zaposleni še komunikologi, politologi in inženirji elektrotehnike. Na področju regionalnega razvoja v regijah trenutno deluje 6 geografov ali $5 \%$ vseh zaposlenih.

Tretjinska zaposlitev in honorarno sodelovanje $\mathrm{v}$ regionalnih razvojnih agencijah nista močno razširjena, saj je le 5 sodelavcev v tretjinskem delovnem razmerju. 6 ljudi je zaposlenih honorarno. Zaposleni za krajši delovni čas ali honorarno zaposleni so predvsem ekonomisti in sociologi. 
V 19 regionalnih razvojnih agencijah v Sloveniji je po razpoložljivih podatkih zaposlenih skupaj 121 ljudi. Razmerja v izobrazbi med posameznimi kadri so zelo podobna razmerju pri redno zaposlenih.

Regionalne razvojne agencije si pri pripravi regionalnih razvojnih programov in pri izvajanju drugih aktivnosti pomagajo z zunanjimi sodelavci. Izobrazba 90 zunanjih sodelavcev je bolj uravnotežena. Še vedno prevladujejo ekonomisti, vendar njihov delež ne presega četrtine (24 \%). Izstopa delež arhitektov (11\%). Sledijo agronomi in geografi z $9 \%$.

V letu 2002 je predvidena zaposlitev 23 novih delavcev. Zaposlitve se lahko veselijo predvsem kandidati z znanjem ekonomije (22\%) in organizatorji dela (17\%). Novega dela se bo predvidoma lahko veselil 1 geograf.

Regionalne razvojne agencije si želijo zaposliti še veliko delavcev. V svojih željah so navedli, da bi želeli vzeti v redno delovno razmerje 53 ljudi. Največje bi bilo povpraševanje po pravnikih (17\%), ekonomistih (15\%), krajinskih arhitektih (11\%) in administrativnem osebju (11\%). Potrebni bi bili trije geografi $(6 \%)$.

Regionalni pregled po Sloveniji razkrije, da je največ geografov udeleženih pri delu regionalnih razvojnih agencij v Gorenjski statistični regiji. Na zahodu Slovenije so geografi bolj aktivni v procesu inštitucionalnega regionalnega planiranja. Geografi pri delu regionalnih razvojnih agencij ne sodelujejo $\mathrm{v}$ Prekmurski, Koroški, Savinjski, Posavski, Obalno kraški in v Osrednjeslovenski statistični regiji. Če upoštevamo planske regije oziroma regije, za katere se izdelujejo regionalni razvojni programi, potem je prisoten geograf v Obalnokraški regiji, ni pa ga v Notranjski regiji.

Želje po sodelovanju z geografi so. Po najbolj optimističnem scenariju geografi na podlagi zbranih podatkov zaenkrat ne bodo sodelovali pri izdelavi regionalnih razvojnih programov v Koroški, Savinjski, Osrednjeslovenski, Notranjski in Spodnjeposavski statistični regiji.

Z geografi je sodelovalo že kar nekaj regionalnih razvojnih agencij. Le tri agencije od 16-ih še niso sodelovale $\mathrm{z}$ geografi.

Agencije, ki so že sodelovale z geografi, so se o njih izrazile zelo pohvalno. Pomen geografov pri njihovem delu so označile kot pozitiven in zelo pozitiven. Pomen geografov pri delu regionalno razvojnih agencij je glede na rezultate ankete zelo pomemben in pripomore $\mathrm{k}$ njihovemu uspešnemu delu.

Kot prednosti geografov se največkrat omenja njihova sposobnost analize. Sledita njihova sposobnost razumevanja procesov v pokrajini ter razumevanje dejavnikov v regiji. Pri geografih cenijo njihovo sposobnost sinteze ter strokovnost pri delu. 
Slika 2: Ocena pomena geografov v regionalnih razvojnih agencijah. $N=13$.

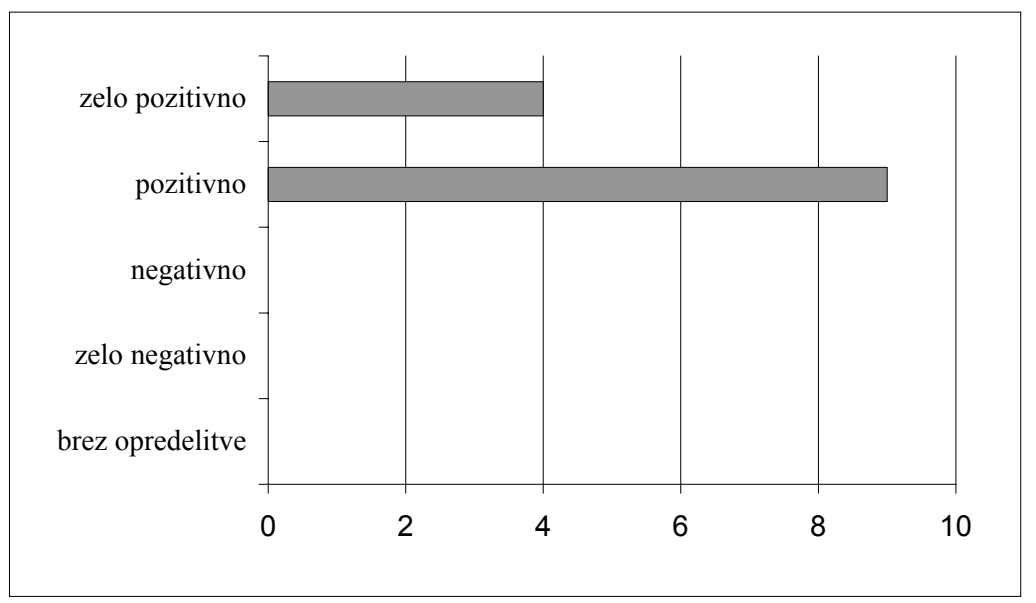

Slika 3: Prednosti geografov pri delu regionalnih razvojnih agencij. $N=13$.

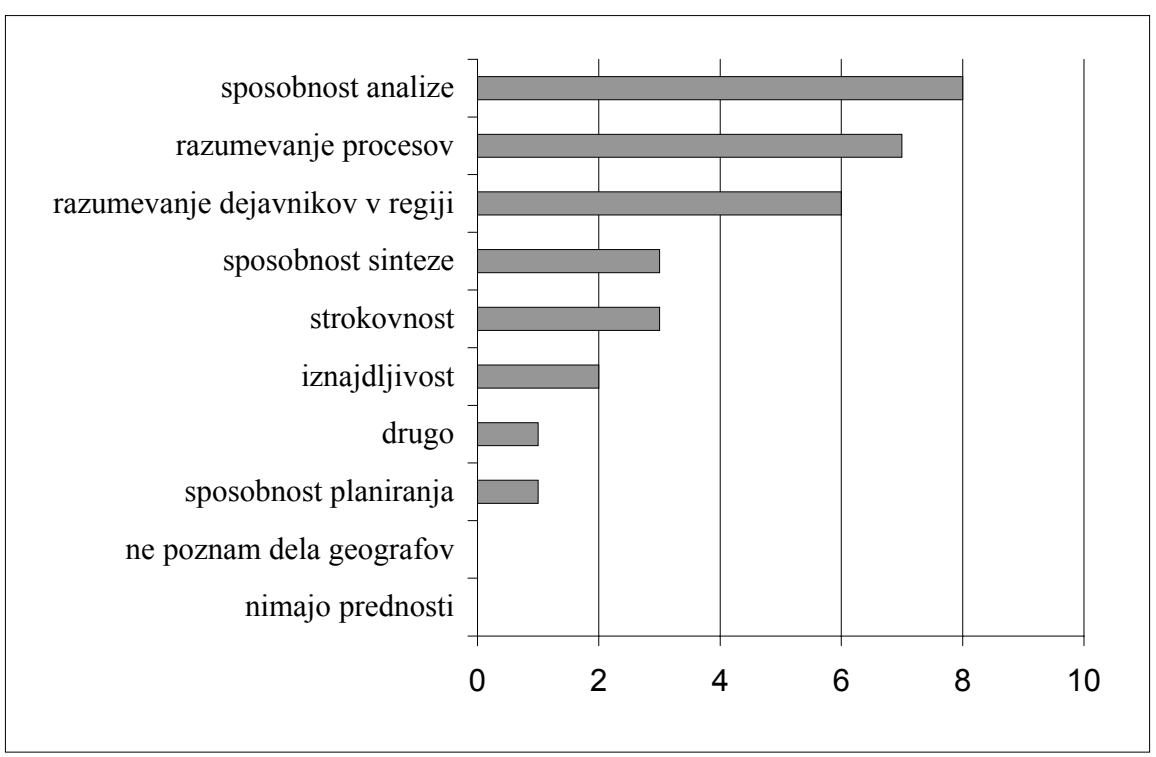

Kot slabost se največkrat izkaže njihovo omejeno znanje, kar pa je v nasprotju $\mathrm{z}$ visoko uvrstitvijo njihove sposobnosti razumevanja dejavnikov in procesov v pokrajini, saj je za njihovo določitev potrebno široko znanje. Izkušnje treh 
agencij govorijo o tem, da geografi nimajo specifičnih slabosti, ki bi jih bilo potrebno posebej izpostavljati. Nekatere agencije se pritožujejo nad omejeno sposobnostjo geografov sintetizirati zbrane podatke, vendar sta tako odgovorili le dve agenciji od devetih. Kot slabosti geografov so bili omenjeni še pomanjkanje znanj iz ekonomije, projektivnega vodenja, geografskih informacijskih sistemov ter drugih računalniških programov.

Slika 4: Slabosti geografov. $N=9$.

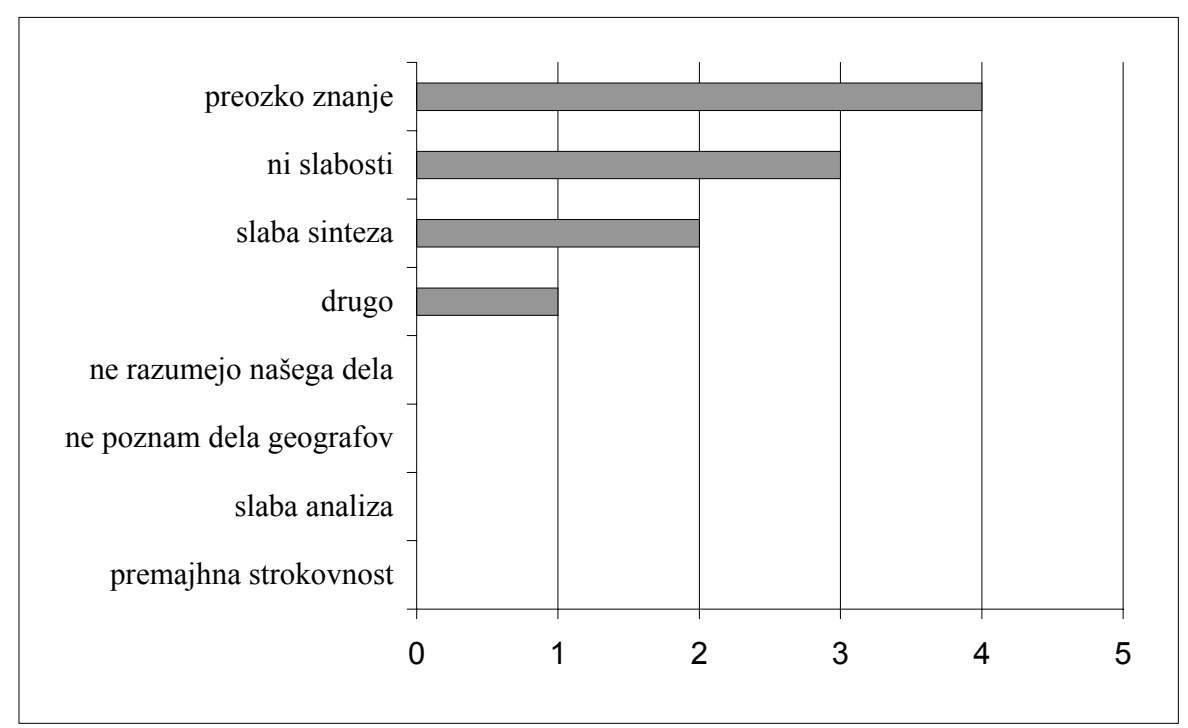

\section{SKLEP}

Iz anketnih listov je jasno, da razvojno politiko na regionalnem nivoju vodijo predvsem ekonomisti, saj predstavljajo preko $40 \%$ vseh zaposlenih v regionalnih razvojnih agencijah. Zaposleni z ostalo vrsto izobrazbe so številčno relativno enakomerno razporejeni. Med njimi je 6 geografov ali 5\% vseh zaposlenih. Geografi so tudi zunanji sodelavci regionalnih razvojnih agencij. Njihov relativni delež (9\%) je višji od deleža zaposlenih geografov.

Visoko število ekonomistov, ki delajo v regionalno razvojnih agencijah, je delno posledica organizacije agencij, saj večje število sodelujočih inšitucij izhaja iz podjetniških pospeševalnih centrov oziroma je še vedno njihova glavna naloga pomoč podjetnikom.

$\mathrm{Ob}$ tem se ni mogoče izogniti vtisu, da je v slovenskih regijah v ospredju predvsem ekonomski vidik regionalnega planiranja. Ekonomsko regionalno pla- 
niranje je mogoče primerno za doseganje ciljev učinkovitosti nacionalnega gospodarstva in konkurenčnosti države. Toda pravo regionalno planiranje skuša z usklajevanjem ekonomskega, socialnega in prostorskega razvoja ter varstvom okolja doseči ustrezen (trajnostni) regionalni razvoj in ne le trajno regionalno rast. Cilj regionalnega planiranja je ob timskem delu strokovnjakov različnih ved, politikov, podjetnikov in ob sodelovanju javnosti mogoče doseči. Skromna zastopanost geografov v nekaterih delih Slovenije je zato z vidika upoštevanja prostorske in okoljske dimenzije $\mathrm{v}$ regionalnih razvojnih programih problematična.

Pomen geografije pri regionalnem planiranju je po teoretični plati zelo velik (Vrišer, 1978). S pomočjo ankete je bilo ugotovljeno, da postavljeno hipotezo o pomenu geografije lahko potrdimo, lahko pa jo ovržemo. Če upoštevamo število geografov in zunanjih sodelavcev, potem jo je potrebno ovreči. Glede na rezultate anket o pomenu geografov ter njihovih lastnostih in prednostih pa hipoteza drži, saj je delo geografov visoko cenjeno. Omenjene so njihove prednosti, ki jih je več kot slabosti. Nekatere regionalne razvojne agencije $\mathrm{v}$ delu geografov slabosti, ki bi jih bilo potrebno posebej izpostaviti, ne vidijo.

Regionalne razvojne agencije pri geografih moti predvsem preozko znanje, pomanjkljiva sinteza ter pomanjkanje znanj iz ekonomije, projektnega vodenja in GIS aplikacij. V Sloveniji ni dodiplomske šole za regionalno planiranje. Vsak, ki dela na področju regionalnega planiranja, se mora še dodatno izobraziti, da je kos zadanim nalogam. Postmoderni pristop k planiranju zahteva poleg obvladovanja lastnega področja dela in teorije planiranja znanja iz menedžmenta, ekonomije in marketinga.

Geografi imajo v primerjavi z drugimi strokovnjaki dve veliki prednosti: Druge znanstvene discipline so močne $\mathrm{v}$ razlaganju posameznih dejavnikov, vendar nobena od njih ne preučuje njihovega medsebojnega součinkovanja in vpliva na oblikovanje pokrajine. Geografi v času študija pridobijo široko znanje, ki lahko služi povezovanju dela različnih strokovnjakov. Pri timskem delu bi morali svoje sposobnosti glasneje promovirati in sodelovati ne samo v regionalni analizi, ki jo hvalijo vsi po vrsti, ampak tudi pri pripravi programov, podprogramov in projektov z ustrezno mero samoiniciativnosti, ustvarjalne domišljije in s predvidevanjem, kako bodo odločitve posegle $\mathrm{v}$ številne dejavnike in njihovo medsebojno součinkovanje, ki oblikujejo regionalno stvarnost. Po mnenju nekaterih je velika prednost geografov ravno $\mathrm{v}$ tem, da probleme predstavijo z druge plati.

Pomen geografije $v$ inštitucijah regionalnega planiranja je odvisen od dela geografov. Če ti dobro opravljajo svoje delo, potem ima geografija pomembno aplikativno vrednost. Iz rezultatov ankete je razvidno, da geografi dobro opravljajo svoje delo geografov in planerjev. Regionalnih razvojnih agencij ni 
mogoče prisiliti, da bi zaposlile geografa. Izkušnje iz regionalnih razvojnih agencij, ki geografe že imajo, bodo privedle do večje ali pa manjše veljave geografov in geografije v ostalih inštitucijah. Glavna teža pomena geografije je na geografih samih.

$\mathrm{V}$ prihodnje bi bilo zanimivo narediti primerjalno analizo regionalnih razvojnih programov, da bi ugotovili, kako se sodelovanje geografov odraža $\mathrm{v}$ vsebini strateškega in izvedbenega dela.

\section{Zahvala}

Avtor se vljudno zahvaljuje vsem regionalnim razvojnim agencijam in njihovim uslužbencem, ki so sodelovali pri raziskavi.

\section{Literatura:}

Drozg, V., Premzl, V., 1999. Instrumenti regionalne politike v Sloveniji. IB revija, 33, št. 2-3, 76-83.

Kavaš, D., Strmšnik, I., Pečar, J., 2000. Reforma slovenske regionalne politike: oblikovanje slovenske regionalne strukturne politike. Geographica Slovenica 33, II, 83-132.

Kukar, S., 1995. Regional challanges of a small open economy: The case of Slovenia. Local and Regional Development During the 1990s Transition in Eastern Europe. Aldershot, Avebury, 119-136.

Navodilo o minimalni obvezni vsebini in metodologiji priprave ter načinu spremljanja in vrednotenja regionalnega razvojnega programa. Uradni list $\mathrm{RS}, 52 / 00$ in $111 / 00$.

Ravbar, M., 2000: Regionalni razvoj slovenskih pokrajin. Geographica Slovenica 33, II, 9-81.

Seznam registriranih regionalnih razvojnih agencij na Agenciji Republike Slovenije za regionalni razvoj. Medmrežje. http://www.sigov.si/arr/. Citirano 14. maja 2002.

Vrišer, I., 1978. Regionalno planiranje. Ljubljana, Mladinska knjiga, 3-286.

Vrišer, I., 1992. Uvod v geografijo. Ljubljana, Univerza v Ljubljani, Filozofska fakulteta, Oddelek za geografijo, 5-37.

Vrišer, I., 1999. Regionalni razvoj slovenskih pokrajin in občin. Ib revija, 33, št. 2-3, 47-67.

ZSRR: Zakon o spodbujanju skladnega regionalnega razvoja. Uradni list RS, št. $60 / 99$. 


\title{
GEOGRAPHERS AND GEOGRAPHY IN THE INSTITUTIONS OF REGIONAL PLANNING
}

\begin{abstract}
Summary
Slovenia is facing with different challenges in the field of regional development. Some of them are endogenous, like the change of political system, the independence in 1991, a way toward the full membership in the European union, others are exogenous (globalisation, post-fordism, disintegration of Yugoslavia and integration processes in the European continent).

The system of helping demographic endangered areas in Slovenia in of the ninethies was no longer appropriate. Because of the accession into the European union the harmonisation of the regional development practise was needed. The result emerged in 1999 when a new regional development and planning legislation was introduced.

The new law legitimised regional development agencies as institutional basis for regional development in regions. The lack of the second level of selfgovernment caused that spatial units for regional development purposes are statistical regions (NUTS 3 level).

New organisation of regional development needs many changes in the institutional organisation of the country and particularly the regions. To establish regional agencies a lot of new staff is needed. Regional planning is a complex task. A lot of scientific disciplines must be involved in order to achieve the final aim of regional planning. Geography is one of them.

The question is, how important are geographers in the field of regional planning in Slovenia today. We assume, that geography has an important applicative role. Our task was to figure out the number of geographers that work in regional development institutions, to discover potential new employments and to find out advantages and disadvantages of geographers who are working in the field of regional planning.

To achieve the aim of our research a questionnaire was sent to all regional and local development agencies, ministries responsible for regional development and some selected private companies that are active in creating regional or local regional development programs. We asked them to inform us about the number of fully employed staff, part time employment and new employments in 2002. There was also a question what kinds of staff would they need. Advantages and disadvantages of geographers were also mentioned.

Questionnaire was returned from 19 agencies out of 25 . We covered all statistical regions in Slovenia. The sample is $76 \%$ of the whole population. The governmental agencies are not included into the following summary.
\end{abstract}


There are 110 fully employed people of different occupations in regional development agencies. Economists represent $41 \%$ of all employees. Almost one-third $(27 \%)$ persons did not suit into any of the given occupations. 6 geographers $(5 \%)$ are active in the field of regional development.

Part time job is not so popular. The final number of employed persons in regional development agencies is only slightly different from those of the fully employed, but proportions are the same.

Regional development agencies have 90 outer participants that are involved into their projects. Most of them are economists. $9 \%$ of them are workers with the degree in geography.

23 new jobs will be opened in regional development agencies in the year 2002. Economists are wanted the most. Only one geographer can hope to get a job. But that is not all. Regional development agencies would need at least 53 new employees including 3 geographers $(6 \%)$.

Most geographers are present in regional development agencies in the western part of Slovenia, esspecially in Gorenjska region. By the most optimistic variant geographers won't participate in preparing regional development programs in 5 regions.

The most ordinary answer to the question of advantages of geographers is their ability of analyse. The second and the third one are understanding of processes and factors that emerge in regions. The unability to make a synthesis is their biggest disadvantage. Geographers are supposed to be bad in economy, management and in GIS applications. Some agencies answered, that geographers don't have disadvantages that should be specially pointed to.

It seems that according to the number of geographers involved into regional planning in Slovenia today, geography is not an important discipline. The problem might be the incorporation of spatial and environmental issues in regional development plans. However, according to positive evaluation scores of the contribution of geographers in the work of regional development agencies we can say, that geography has an important applicative role in the field of regional development in Slovenia today. 